\title{
Perangkat Pembelajaran Berbasis Problem Slolving Tri Hita Karana Materi Keragaman Budaya Kelas IV SD
}

\section{Gusti Made Adi Suputra1*, I Wayan Sujana²}

1,2 Program Studi Pendidikan Guru Sekolah Dasar, Universitas Pendidikan Ganesha, Singraja, Indonesia

\section{ART ICLE INFO}

Article history:

Received 28 Februari 2021

Revised 30 April 2021

Accepted 23 Mei 2021

Available online 25 Juni 2021

\section{Kata Kunci:}

Perangkat Pembelajaran, Problem solving, Tri Hita

Karana

Keywords:

Learning Tools, Problem solving, Tri Hita Karana

\begin{abstract}
A B S T R A K
Rendahnya hasil belajar siswa pada mata pelajaran IPS dan belum tersedia perangkat pembelajaran berbasis problem solving yang diterapkan pada muatan materi IPS di kelas IV. Oleh karena itu, penelitian ini bertujuan mengembangkan perangkat pembelajaran berbasis problem solving Tri Hita Karana untuk muatan materi IPS pada siswa kelas IV. Jenis penelitian ini yaitu penelitian Pengembangan menggunakan model ADDIE (Analyzed, Design, Development, Implementation, Evaluation). Subjek penelitian ini adalah 1 ahli isi pembelajaran, 1 ahli desain pembelajaran, 1 ahli media pembelajaran. Metode pengumpulan data yang digunakan berupa angket atau kuesioner, wawancara. Instrumen yang digunakan yaitu menggunakan kuesioner atau angket. Teknik analisis yang digunakan dalam penelitian ini yaitu teknik analisis deskriptif kualitatif dan kuantitatif. Hasil penelitian ini menyimpulkan bahwa hasil uji ahli isi mata pelajaran diperoleh skor
\end{abstract} 95\% (sangat baik), hasil uji ahli desain diperoleh skor 95,45\% (sangat baik), hasil uji ahli media diperoleh skor $93,18 \%$ (sangat baik), hasil uji coba perorangan diperoleh dengan skor 93,17\% (sangat baik). Jadi media perangkat pembelajaran layak digunakan dalam pembeajaran muatan IPS di kelas IV sekolah dasar. Implikasi dari penelitian ini yakni secara empiris terbukti bahwa menggunakan perangkat pembelajaran yang dikembangkan layak digunakan oleh guru dalam pembelajaran.

\begin{abstract}
A B S T R A C T
The low learning outcomes of students in social studies subjects and problem solving-based learning tools are not yet available that are applied to the content of social studies material in class IV. Therefore, this study aims to develop problem solving-based learning tools for social studies content for fourth grade students. This type of research is development research using the ADDIE model (Analyzed, Design, Development, Implementation, Evaluation). The subjects of this study were 1 learning content expert, 1 learning design expert, 1 learning media expert. Data collection methods used in the form of questionnaires or questionnaires, interviews. The instrument used is using a questionnaire or questionnaire. The analytical technique used in this research is descriptive qualitative and quantitative analysis techniques. The results of this study concluded that the results of the subject matter expert test obtained a score of 95\% (very good), the results of the design expert test obtained a score of $95.45 \%$ (very good), the results of the media expert test obtained a score of $93.18 \%$ (very good), individual trial results obtained with a score of $93.17 \%$ (very good). So the media of learning devices is suitable for use in teaching social studies content in grade IV elementary schools. The implication of this research is that it is empirically proven that using the learning tools developed is suitable for use by teachers in learning.
\end{abstract}

\section{Pendahuluan}

IPS merupakan ilmu pengetahuan yang mengkaji berbagai disiplin ilmu sosial dan humaniora serta kegiatan dasar manusia yang dikemas secara ilmiah dalam rangka memberi wawasan dan pemahaman yang mendalam kepada peserta didik, khususnya di tingkat dasar dan menengah (M. R. S. Dewi, Murda, \& Pudjawan, 2019; Puspitasari \& Murda, 2018). IPS merupakan ilmu pengetahuan yang meninjau berbagai disiplin ilmu sosial dan humaniora serta kegiatan dasar manusia yang disajikan secara

Copyright (C) Universitas Pendidikan Ganesha. All rights reserved 
ilmiah guna memberikan pemahaman dan wawasan yang mendalam bagi peserta didik (Dewi, Wiyasa, \& Asri, 2017; Widnyana, Sujana, \& Putra, 2017). Hakikat pendidikan IPS yang dikembangkannya berdasarkan realita kondisi sosial budaya yang ada di lingkungan siswa, sehingga dengan ini akan dapat membina warga negara yang baik yang mampu memahami dan menelaah secara kritis kehidupan sosial di sekitarnya, serta mampu secara aktit berpartisipasi dalam lingkungan kehidupan, baik di masyarakatnya, negara, maupun dunia (Antari, Sujana, \& Wiarta, 2013). Untuk memudahkan guru dalam melaksanakan pembelajaran tentunya diperlukan perangkat pembelajaran berupa RPP, bahan ajar, dan LKPD yang digunakan guru dalam melaksanakan kegiatan pembelajaran (Purnomo \& Wilujeng, 2016; Qondias, Winarta, \& Siswanto, 2019). Perangkat pembelajaran adalah komponen yang harus di siapkan oleh guru sebelum melaksanakan proses pembelajaran di kelas (Nugroho, 2018; Rusnilawati, 2016). Perangkat adalah suatu alat atau perlengkapan, sedangkan pembelajaran adalah suatu proses atau cara menjadi orang belajar (Afdhal \& Sugiman, 2018). Perangkat pembelajaran menjadi pegangan bagi guru dalam melaksanakan pembelajaran baik di kelas, luar atau laboratorium kelas. Perangkat pembelajaran biasanya terdiri dari silabus, RPP, instrumen penilaian.

Namun pada kenyataanya terkadang guru jarang menyusun RPP dan LKS dikarenakan mereka merasa telah terbiasa untuk mengajar di kelas, selain itu, RPP yang dibuat tidak memuat rincian aktivitas yang mengakomodasi proses berpikir dan bernalar siswa (Hapsari, Rambita, \& Tindangen, 2018; Nugroho, 2018). Selama ini siswa masih menggunakan perangkat pembelajaran yang disiapkan sekolah atau dibeli dari penerbit, yang umumnya berupa LKS dan buku ajar (Dwitantra, 2015; Hidayatulloh et al, 2015). Namun, perangkat pembelajaran yang telah tersedia masih kurang didukung dengan komponen penilaian lainnya seperti lembar observasi keterlaksanaan RPP, angket respon siswa, serta lembar penilaian afektif dan psikomotor, sehingga acuan penilaian hasil belajar masih terbatas. Hal ini juga terjadi di SD Negeri 5 Pedungan, berdasarkan hasil observasi dan wawancara yang telah dilakukan diketahui bahwa RPP yang digunakan guru sudah mengacu kepada standar proses pembelajaran namun belum mengarahkan siswa untuk terlibat aktif dalam pelaksanaan pembelajaran dan belum menuntun siswa untuk mengembangkan pengetahuannya khususnya dalam meningkatkan kemampuan pemecahan masalah. Langkah-langkah pembelajaran yang termuat dalam RPP merupakan kegiatan yang rutin dilakukan oleh siswa dan belum mengarahkan siswa untuk menggunakan kemampuan pemecahan masalah dalam kehidupan sehari-hari. Selain itu, dalam pelaksanan pembelajaran guru masih jarang menggunakan LKPD sebagai media untuk mengarahkan siswa dalam mencapai tujuan pembelajaran. Hal ini juga menyebabkan kurangnya interaksi antar siswa di dalam kelas dalam proses pembelajaran. Sehingga, untuk meningkatkan aktivitas siswa dalam pembelajaran perlu diadakanya pembaharuan pada perangakt pembelajaran tersebut.

Salah satu cara untuk memecahkan masalah tersebut adalah mengembangkan perangkat pembelajaran berupa RPP dan LKPD berbasis Problem Solving. Problem Solving merupakan salah satu model pembelajaran yang dapat memecahkan suatu permasalahan secara cepat dan tepat berdasarkan berbagai sudut pandang dan bukan hanya berdasar pada satu sudut pandnag tertentu (Manurung \& Panggabean, 2020; Setyadi, Sudiarta, \& Mertasari, 2019). Model pemecahan masalah yang memancing cara berfikir siswa dlam memecahkan masalah yang diberikan (Nuraziza \& Suwarma, 2018; Retnowati, Yazid Fathoni, \& Chen, 2018). Berdasarkan hasil penelitian tersebut, maka dapat disimpulkan bahwa didalam pembelajaran penggunaan perangkat pembelajaran berbasis problem solving sangat efektif digunakan karena dengan adanya perangkat pembelajaran proses pembelajaran akan berlangsung dengan baik terutama karena beberapa faktor pendukung salah satunya yakni penggunaan basis perangkat pembelajaran yakni problem solving (Saguni, 2013; Sakaningsih, Asri, \& Negara, 2014). Pembelajaran dengan problem solving menyediakan kondisi untuk meningkatkan keterampilan berfikir kritis dan anlitis serta memecahkan masalah kompleks dalam kehidupan nyata sehingga akan memunculkan "budaya berfikir" pada diri siswa (Pramestika, Suwignyo, \& Utaya, 2020).

Perangkat pembelajaran yang dikembangkan nantinya akan dikemas dalam bentuk perangkat pembelajaran berbasis Tri Hita Karana karena pada era gobalisasi sekarang nilai-nilai kearifan lokal sangat penting untuk diajarkan kepada siswa agar nantinya siswa dapat mengimplementasikannya dalam kehidupannya supaya siswa nantinya tidak terjerumus kedalam pengaruh perkembangan era globalisasi yang tidak baik (Indrawan, Manuaba, \& Sujana, 2017; Widiartini, Putra, \& Manuaba, 2018; Widnyana et al., 2017). Tri Hita Karana berasal dari kata tri = tiga, hita = kebahagiaan $/$ kemakmuran $/$ kesejahteraan, dan karana = penyebab. Jadi, Tri Hita Karana adalah tiga hal yang menyebabkan hubungan harmonis atau kebahagian hidup yakni hubungan manusia dengan Tuhan (parhyangan), hubungan manusia dengan manusia (pawongan), dan hubungan manusia dengan lingkungan (palemahan). Tri Hita Karana yang dapat mendukung tujuan pembelajaran tersebut (Suniasih, \& Sujana, 2017; Aryantini, Agung, \& Dantes, 2018). Tri Hita Karana itu sendiri memiliki pengertian tiga hal penyebab kebahagiaan manusia. Tri Hita Karana adalah sebuah konsep kearifan lokal Bali yang menekankan pada keseimbangan hidup sebagai penyebab kebahagiaan. Terdapat tiga unsur dalam konsep Tri hita karana yaitu Parahyangan (hubungan manusia 
dengan tuhan), Pawongan (hubunga manusia dengan manusia), Palemahan (hubungan manusia dengan alam). Konsep Tri Hita Karana sangat cocok dipadukan dengan perencanaan pembelajaran problem solving, dimana pada pada metode ini guru akan berinteraksi dengan siswa untuk memecahkan masalah secara individu ataupun secara bersama-sama. Implementasi tri hita karana bagian parhyangan terlihat pada saat guru dan siswa melaksanakan persembahyangan saat mengawali dan mengakhiri pembelajaran (Suryantari, Suadnyana, \& Wulandari, 2018).

Temuan sebelumnya menyatakan bahwa pembelajaran dengan problem solving dapat membantu siswa memahami materi pembelajaran dengan mudah (Ilmi, 2019; Irawana \& Taufina, 2020). Temuan penelitian lainnya juga menyatakan bahwa pembelajaran dengan problem solving dapat meningkatkan hasil belajar siswa secara signifikan (Nuraziza \& Suwarma, 2018; Retnowati et al., 2018). Belum adanya kajian pengenai perangkat pembelajaran berbasis problem solving Tri Hita Karana dengan Materi Keragaman Budaya. Tujuan penelitian ini yaitu untuk menciptakan perangkat pembelajaran berbasis problem solving Tri Hita Karana dengan Materi Keragaman Budaya. Diharapkan perangkat pembelajaran berbasis problem solving Tri Hita Karana dapat meningkatkan semangat siswa dalam belajar sehingga dapat meningkatkan hasil belajar siswa.

\section{Metode}

Penelitian ini merupakan penelitian pengembangan yang dikenal dengan (R\&D) research and development dengan menggunakan model ADDIE yang terdiri dari analisis (analysis), desain (design), pengembangan (development), implementasi (implementation), dan evaluasi (evaluation) (Tegeh, 2014). Pemilihan model ini dikarenakan model ADDIE menggunakan pendekatan sistem yang dapat membagi proses perencanaan pembelajaran ke beberapa langkah yang memiliki urutan-urutan logis. Subjek penelitian ini adalah dosen yang memiliki latar belakang teknologi pendidikan yaitu dosen ahli isi pembelajaran, dosen ahli desain pembelajaran, dosen ahli media pembelajaran dan siswa kelas VI SD Negeri 5 Pedungan. Data yang diperlukan dalam penelitian ini yaitu data review ahli, data hasil uji coba perorangan. Metode pengumpulan data yang digunakan berupa angket atau kuesioner, wawancara. Instrumen yang digunakan yaitu menggunakan kuesioner atau angket. Data yang terkumpul dalam penelitian ini berupa skor hasil dari pengisian kuesioner, saran, komentar dan masukan terkait produk yang dikembangkan. Teknik analisis yang digunakan dalam penelitian ini yaitu teknik analisis deskriptif kualitatif dan kuantitatif. Teknik analisis ini digunakan untuk mengolah data kualitatif yang diperoleh melalui angket berupa saran, masukan, komentar yang diberikan sedangkan untuk data kuantitatif diperoleh melalui angket dalam bentuk skor yang kemudian dikonversikan menjadi persentase menggunakan konversi tingkat pencapaian skala lima.Adapun kisi-kisi instrumen pada tahap validitas dan tahap uji coba dalam penelitian ini dapat disajikan pada tabel berikut ini.vAdapun kisi-kisi instrumen pada tahap validitas dan tahap uji coba dalam penelitian ini dapat disajikan pada Tabel 1, 2, 3 dan 4.

Tabel 1. Kisi-kisi Instrumen Ahli Isi Materi

\begin{tabular}{cccl}
\hline No. & Aspek & & \multicolumn{1}{c}{ Indikator } \\
\hline & & a. & Materi dalam perangkat pembelajaran sesuai dengan kompetensi dasar \\
1. & Kurikulum & b. & Materi dalam perangkat pembelajaran sesuai dengan indikator \\
& & & pembelajaran \\
& & c. & Materi dalam perangkat pembelajaran sesuai dengan tujuan pembelajaran \\
& & a. & Cakupan materi sesuai dengan karakteristik siswa kelas IV \\
& b. & Konsep dipaparkan dengan benar \\
& & c. & Materi disajikan secara sistematis \\
2. & Materi & d. & Kejelasan uraian materi dengan contoh-contoh yang diberikan \\
& & e. & Penerapan yang dilakukan dalam perangkat pembelajaran mendukung \\
& & f. & Konsep materi \\
& & g. & Soal-soal yang disajikan melatih siswa berpikir tingkat tinggi (HOTS) \\
\hline
\end{tabular}

Tabel 2. Kisi-kisi Instrumen Ahli Desain Pembelajaran

\begin{tabular}{ccrl}
\hline No & Aspek & & \multicolumn{1}{c}{ Indikator } \\
\hline \multirow{3}{*}{1} & & a. & $\begin{array}{l}\text { Rumusan tujuan pembelajaran disusun dengan jelas sesuai dengan } \\
\text { Tujuan }\end{array}$ \\
& b. & Tormat ABCD (audience, behavior, condition, degree. \\
& & c. & Konsistensi antara tujuan pembelajaran, materi, dan evaluasi \\
& & &
\end{tabular}




\begin{tabular}{llll}
\hline No & Aspek & & \multicolumn{1}{c}{ Indikator } \\
\hline & & a. & Penyampaian materi sesuai dengan materi pembelajaran \\
& & b. & Mampu memfasilitasi siswa untuk belajar secara mandiri \\
& & c. & Menjelaskan contoh-contoh keberagaman budaya sesuai dengan \\
& \multirow{2}{*}{ Strategi } & & materi \\
& & d. & Materi memberikan daya tarik perhatian siswa \\
& & e. & Kelengkapan informasi materi sesuai dengan sumber \\
& & f. & Memberikan motivasi belajar kepada siswa \\
& & a. & Petunjuk pengerjaan soal jelas \\
& \multirow{2}{*}{ Evaluasi } & b. & Tes sesuai dengan indikator \\
\hline
\end{tabular}

Tabel 3. Kisi-kisi Instrumen Ahli Media Pembelajaran

\begin{tabular}{|c|c|c|}
\hline No & Aspek & Indikator \\
\hline 1. & Teknis & $\begin{array}{l}\text { a. Media power point dapat dilihat dengan mudah. } \\
\text { b. Informasi yang disampaikan dalam power point mudah di pahami. } \\
\text { c. Media LKPD memberikan petunjuk yang jelas } \\
\text { d. Media materi ajar mudah dipahami }\end{array}$ \\
\hline 2. & Tampilan & $\begin{array}{l}\text { a. Kombinasi warna pada desain perangkat pembelajaran menarik } \\
\text { b. Tulisan dalam perangkat pembelajaran dapat terbaca dengan jelas } \\
\text { c. Gambar dalam perangkat pembelajaran dapat terlihat dengan jelas } \\
\text { d. Penggunaan jenis huruf yang tepat. } \\
\text { e. Pemilihan background power point sesuai } \\
\text { f. Tampilan pembukaan perangkat pembelajaran menarik } \\
\text { g. Penggunaan ukuran huruf yang tepat. }\end{array}$ \\
\hline
\end{tabular}

Tabel 4. Kisi-kisi Instrumen Uji Perorangan

\begin{tabular}{|c|c|c|c|}
\hline No. & Aspek & Indikator & $\begin{array}{l}\text { Nomol } \\
\text { Butir }\end{array}$ \\
\hline \multirow{5}{*}{1} & \multirow{5}{*}{ Tampilan } & Tayangan/tampilan awal power point menarik & 1 \\
\hline & & Tulisan dalam power point dapat dibaca dengan jelas & 2 \\
\hline & & Gambar dalam power oint dapat dilihat dengan jelas & 3 \\
\hline & & Penjelasan materi dapat dilihat dengan jelas & 4 \\
\hline & & Tampilan warna dalam power point menarik & 5 \\
\hline \multirow{2}{*}{2} & \multirow{2}{*}{ Materi } & Materi yang terdapat pada power point mudah dipahami & 6 \\
\hline & & Uraian materi yang tersaji dalam power point jelas & 7 \\
\hline \multirow[t]{2}{*}{3} & \multirow[t]{2}{*}{ Motivasi } & $\begin{array}{l}\text { Saya senang belajar keberagaman budaya dengan menggunakan } \\
\text { power point, materi ajar pembelajaran }\end{array}$ & 8 \\
\hline & & Perangkat pembelajaran dapat dengan mudah digunakan & 9 \\
\hline \multirow[t]{2}{*}{4} & Penggunaan & Perangkat pembelajaran dapat dilihat secara berulang-ulang & 10 \\
\hline & & Terdapat petunjuk penggunaan yang jelas & 11 \\
\hline
\end{tabular}

Sumber: (Suartama, 2016)

\section{Hasil dan Pembahasan}

Hasil Penelitian pengembangan ini berupa perangkat pembelajaran yang dilengkapi dengan RPP, bahan ajar, LKPD, media power point. Pengembangan perangkat pembelajaran ini menggunakan model ADDIE yang terdiri dari lima tahapan. Tahap pertama yakni tahap analisis. Pada tahap ini dilakukan analisis karakter siswa dengan metode wawancara terhadap guru di SDN 5 Peduangan, Analisi konten hingga memperoleh materi yang tepat, serta analisis fasilitas sekolah. Tahap kedua yakni Desain. Pada tahap ini informasi yang didapatkan pada tahap analisis kemudian digunakan untuk merancang produk dalam bentuk flowchart, story board. Tahap ketiga yakni tahap pengembangan. Pada tahap ini dilakukan pembuatan produk sesuai dengan flowchart dan story board yang telah dibuat. Pembuatan perangkat pembelajaran ini dibuat menggunakan bantuan software MS. Word, MS. Power point. Tahap keempat yakni implementasi. Pada tahap ini dilakukan review ahli terlebih dahulu sebelum dilakukan uji coba kepada siswa. Review ahli dan uji coba terdiri dari uji ahli isi pembelajaran, uji ahli desain pembelajaran, uji ahli media pembelajaran dan uji coba perorangan, hal ini dilakukan untuk mengetahui kelayakan perangkat pembelajaran yang dikembangkan. Tahap kelima yakni tahap evaluasi. Pada tahap ini 
dilakukan evaluasi formatif yang digunakan untuk menilai produk yang dikembangkan. Evaluasi formatif mencangkup validitas oleh para ahli dan uji coba produk. Hasil validitas perangkat pembelajaran berdasarkan hasil review ahli isi pembelajaran, ahli desain pembelajaran, ahli media pembelajaran dan uji coba perorangan. Adapun hasil uji validitas dari pengembangan perangkat pembelajaran menurut para ahli dan uji coba produk dapat disajikan pada Tabel 5.

Tabel 5. Persentase Hasil Uji Validitas Produk

\begin{tabular}{lcc}
\hline \multicolumn{1}{c}{ Subjek Uji Coba } & Hasil Validitas (\%) & Kualifikasi Persentase \\
\hline Uji Ahli Mata Pelajaran & $95 \%$ & Sangat Baik \\
Uji Ahli Media Pembelajaran & $93,18 \%$ & Sangat Baik \\
Uji Ahli Desain Instruksional & $95,45 \%$ & Sangat Baik \\
Uji Coba Perorangan & $93,17 \%$ & Sangat Baik \\
\hline
\end{tabular}

Berdasarkan hasil perolehan data tersebut, bahwa perangkat pembelajaran memiliki validitas sangat baik dan layak digunakan hal ini dapat dilihat dari hasil uji validitas menurut ahli isi pembelajaran mendapatkan persentase 95\% (sangat baik), hasil uji validitas ahli media pembelajaran mendapatkan persentase 93,18\% (sangat baik), hasil uji validitas ahli desain pembelajaran mendapatkan persentase $95,45 \%$ (sangat baik), dan hasil uji coba perorangan mendapatkan persentase 93,17\% (sangat baik). Melalui hasil uji validitas produk diperoleh masukan, saran, dan komentar yang diberikan oleh para ahli dan subjek uji coba produk. Masukan, saran, dan komentar tersebut selanjutnya dijadikan sebagai acuan dalam melakukan perbaikan/revisi produk demi kesempurnaan produk yang dihasilkan. Adapun hasil pengembangan produk media perangkat pembelajaran berbasis problem solvingdapat disajikan dalam gambar 1, 2, 3, dan 4 .

Berdasarkan hasil uji validitas yang telah dilakukan, perangkat pembelajaran yang dikembangkan telah memenuhi kelayakan isi, desain dan media pembelajaran. Selain itu hasil uji coba perorangan yang dilakukan oleh siswa kelas IV SD N 5 Pedungan juga memberikan respon yang positif terkait perangkat pembelajaran yang dikembangkan, sehingga perangkat yang dikembangkan layak digunakan dalam pembelajaran. Perangkat pembelajaran layak digunakan dalam proses pembelajaran hal ini disebabkan oleh beberapa faktor yaitu sebagai berikut. Pertama, perangkat pembelajaran layak digunakan dalam proses pembelajaran karena sesuai dengan pembelajaran. Pada perangkat pembelajaran ini indikator, kompetensi dasar dan tujuan pembelajaran yang terdapat pada perangkat pembelajaran sudah sesuai dengan karakteristik pembelajaran dan kompetensi yang dimiliki siswa. Kesesuain perangkat pembelajaran dengan karakteristik pembelajaran akan memudahkan siswa dalam belajar (Nugroho, 2018; Yerizon, Putri, Musdi, \& Permana, 2020). Selain itu materi yang disajikan pada perangkat epembelajaran juga sudah jelas dan rutut sehingga memudahkan siswa dalam belajar (Hartini, 2017; Prayito, 2011). Selain itu materi yang disajikan dalam perangkat pembelajaran sudah jelas dan runtut serta diperkuat dengan penyediaan contoh-contoh seperti gambar dan animasi yang sesuai dengan materi pembelajaran, sehingga memudahkan siswa dalam menyerap informasi (Atmojo, 2018; Wirdaningsih \& I Made Arnawa, 2017). Penggunaan kalimat dan bahasa dalam perangkat pembelajaran sudah jelas dan sesuai dengan bahasa komunikasi peserta didik dan tingkat kesulitan soal dan kesesuaian soal evaluasi dengan tujuan pembelajaran sudah sesuai membuat siswa lebih mudah memahami materi pembelajaran (Hapsari et al., 2018; Nugroho, 2018).

Kedua, perangkat pembelajaran layak digunakan dalam proses pembelajaran karena mendapatkan kualifikasi sangat baik dari ahli desain instruksional. Hal ini disebabkan karena beberapa poin penting yaitu rumusan tujuan pembelajaran yang terkandung dalam perangkat pembelajaran sudah sesuai dengan indikator pembelajaran. rumusan tujuan pembelajaran harus sesuai dengan perangkat pembelajaran sehingga pembelajaran dapat berjalan dengan baik (Dwitantra, 2015; Rusnilawati, 2016). Penyampaian materi sesuai dengan isi pembelajaran, materi pembelajaran yang terkandung dalam bahan ajar sudah jelas, metode, langkah-langkah pembelajaran, teknik penilaian, dan instrument penilaian yang digunakan dalam lembar kerja peserta didik dalam pembelajaran sudah sesuai sehingga perangkat pembelajaran layak digunakan (Afdhal \& Sugiman, 2018; Rusnilawati, 2016). Ketepatan dalam pemilihan media sehingga memudahkan dalam pembelajaran. proses kegiatan pembelajaran merupakan inti dari kegiatan pendidikan yang berupaya untuk mencapai tujuan pendidikan itu sendiri (Arianti, Wiarta, \& Darsana, 2019; Delfia \& Mayar, 2020; Yuanta, 2019). Berdasarkan penilaian dari ahli desain pembelajaran maka dapat disimpulkan perangkat pembelajaran yang telah dikembangkan sudah valid sehingga dapat digunakan oleh guru untuk mengajar siswa khususnya untuk mata pelajaran IPS pada materi indahnya keragaman di negriku. Proses pembelajaran akan mudah dan mendapatkan hasil yang maksimal jika perencanaan pembelajaran dilakukan dengan baik , serta untuk mengetahui pemahaman siswa dalam 
proses pembelajaran maka diperlukan adanya evaluasi pembelajaran (Ratnawati, Handayani, \& Hadi, 2020; Surjono, 2016). Perancangan pembelajaran melibatkan beberapa aspek seperti: metode pembelajaran, media, dan pendekatan pembelajaran (Dewi, Semara, \& Putra, 2013). Berdasarkan pada pernyataan tersebut dapat disimpulkan bahwa keefektifan siswa untuk mudah memahami pembelajaran dapat dinilai dari karakteristik yang terdapat didalam desain instruksional tersebut. ini sudah baik dari segi desain instruksional.

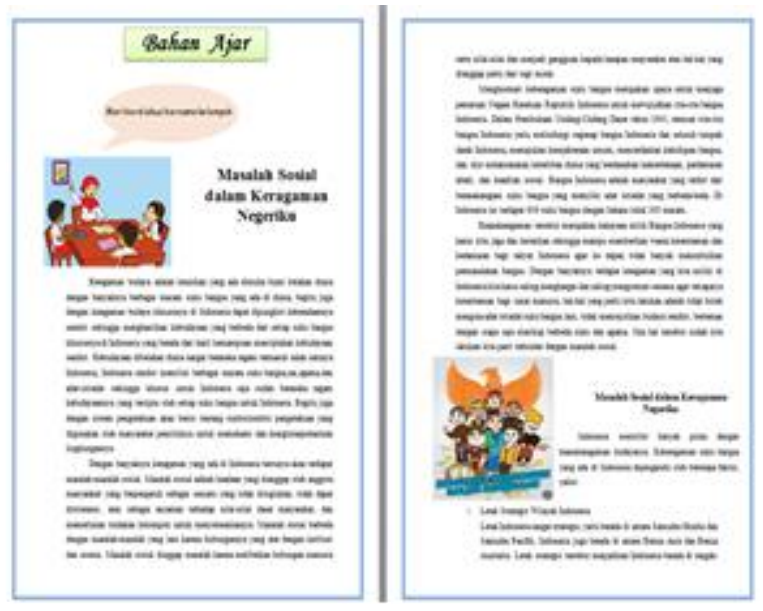

Gambar 1. Tampilan Bahan Ajar

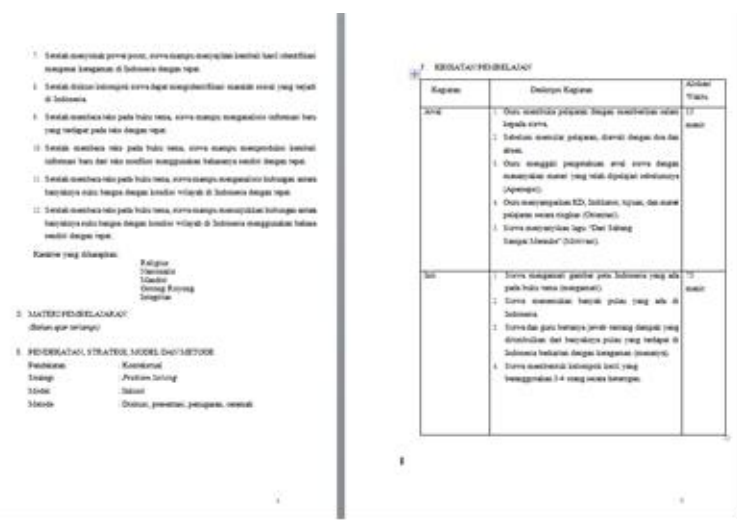

Gambar 3. Tampilan RPP (Rencana Pelaksanaan Pembelajaran)

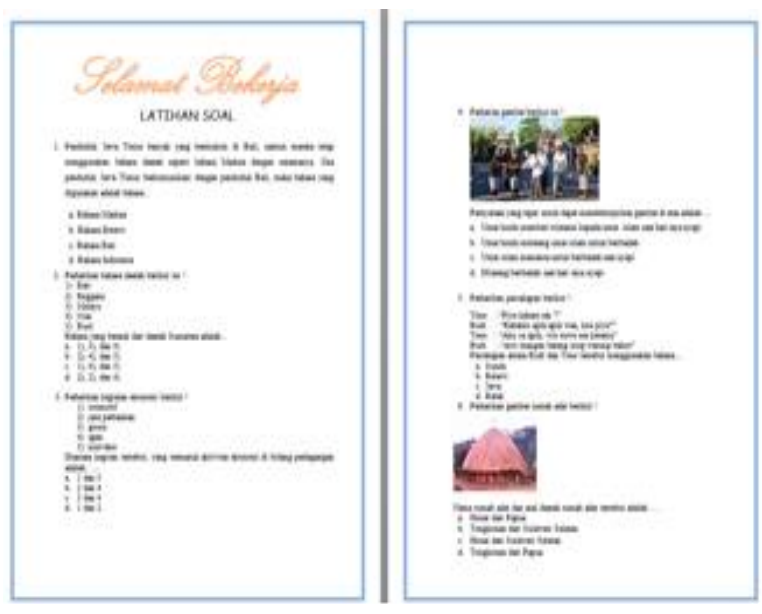

Gambar 2. Tampilan LKPD (Lembar Kerja Peserta Didik)

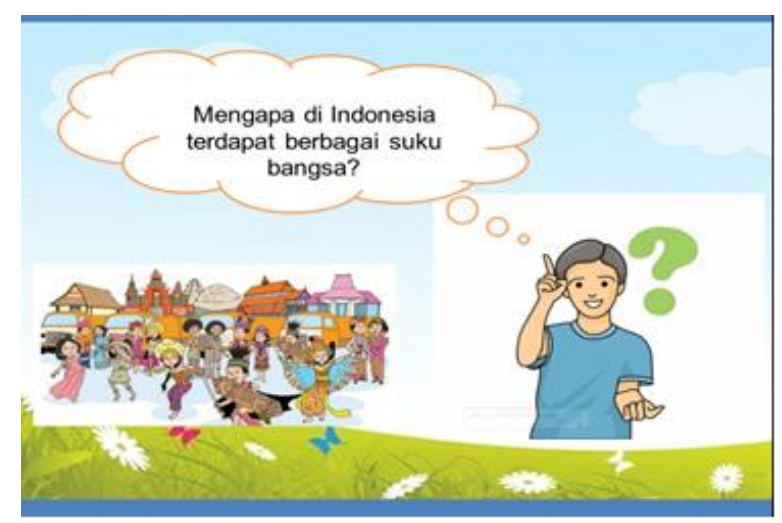

Gambar 4. Tampilan Power Point Materi

Kedua, perangkat pembelajaran layak digunakan dalam proses pembelajaran karena media yang digunakan pada pembelajaran mudah dipahami siswa. Perangkat pembelajaran ini juga menyajikan media pembeajaran yang mudah dipahami oleh siswa. hal ini dapat dilihat pada media memberikan petunjuk yang jelas, media dapat dilihat dengan mudah. Penggunaan huruf yang tepat, kombinasi warna menarik, gambar jelas, pemilihan background sesuai dapat menarik minat siswa dalam belajar (Mediatati \& Suryaningsih, 2017; Widiyasanti \& Ayriza, 2018). Interaktivitas dilihat dari cara siswa dapat memahami atau belajar dengan baik jika siswa sendiri bisa mengendalikan dirinya untuk mengetahui apa yang sedang dipelajari (Elfa, 2017; Istiqlal, 2017; Prasetya, Nur, \& Akbar, 2018). Dengan memberikan pemahaman yang lebih nyata terhadap siswa maka bisa disebut sebagai media pembelajaran yang bagus, hal tesebut bisa dilakukan dengan cara penggabungan berbagai indera yang dimiliki oleh siswa sehingga siswa lebih banyak menyerap materi yang disampaikan dengan media tersebut. Penggunaan media pembelajaran tentunya aka lebih mampu menarik perhatian siswa dalam belajar dan juga membantu guru dala menjelaskan materi yang akan diberikan (Abdurrahman, Jampel, \& Sudatha, 2020; Illahi, Sukartiningsih, \& Subroto, 2018).

Temuan penelitian sebelumnya menyatakan bahwa perangkat pembelajaran yang baik akan dapat memudahkan proses pembelajaran (Hidayatulloh et al., 2015; Nugroho, 2018). Penelitian lainnya juga menyatakan bahwa perangkat pembelajaran yang sesuai juga dapat meningkatkan hasil belajar siswa 
(Hartini, 2017; Prayito, 2011; Wirdaningsih \& I Made Arnawa, 2017). Perangkat pembelajaran yang menarik dapat memotivasi siswa dalam belajar, serta bahasa komunikatif dapat membuat siswa lebih mudah memahami materi pembelajaran. Pengembangan perangkat pembelajaran sangat penting diterapkan karena dengan adanya kombinasi penggunaan media digital dalam proses pembelajaran akan sangat menguntungkan dalam menjembatani proses penyampaian materi kepada siswa selain pembelajaran akan menjadi lebih inovatif. Implikasi penelitian ini yaitu perangkat pembelajaran yang dikembangkan dapat digunakan oleh guru dalam proses pembelajaran.

\section{Simpulan}

Perangkat pembelajaran berbasis problem solving yang dikembangkan layak digunakan dalam pembelajaran IPS jenjang sekolah dasar. Direkomendasikan kepada guru untuk menggunakan perangkat pembelajaran berbasis problem solving yang dapat menciptakan suasana belajar yang menyenangkan sehingga dapat meningkatkan pengetahuan dan hasil belajar siswa terutama pada pelajaran IPS.

\section{Daftar Rujukan}

Abdurrahman, Jampel, I. N., \& Sudatha, I. G. W. (2020). Pengembangan Multimedia Pembelajaran Interaktif untuk Meningkatkan Hasil Belajar IPS. EDUTECH Universitas Pendidikan Ganesha, 8, 32-45. https://doi.org/http://dx.doi.org/10.23887/jeu.v8i1.27049.

Afdhal, M., \& Sugiman, S. (2018). Pengembangan perangkat pembelajaran berbasis reciprocal teaching berorientasi pada antusiasme dan kemampuan berpikir kritis siswa. Pythagoras: Jurnal Pendidikan Matematika, 12(2). https://doi.org/https://doi.org/10.21831/pg.v12i2.17716.

Anjarsari, K. Y., Suniasih, N. W., \& Sujana, I. W. (2017). Pengaruh Model Pembelajaran Talking Chips Berbasis Tri Hita Karana Terhadap Kompetensi Pengetahuan. Mimbar PGSD Undiksha, 5. https://doi.org/http://dx.doi.org/10.23887/jjpgsd.v5i2.10659.

Antari, N. M. W., Sujana, I. W., \& Wiarta, I. W. (2013). Pengaruh Model Reciprocal Teaching (Pembelajaran Terbalik) Berbantuan Multimedia Terhadap Hasil Belajar Ips Siswa Kelas V Sd Gugus I Denpasar Selatan. Mimbar PGSD Undiksha, https://doi.org/http://dx.doi.org/10.23887/jjpgsd.v1i1.967.

Arianti, Wiarta, \& Darsana. (2019). Pengaruh Model Pembelajaran Problem Posing Berbantuan Media Semi Konkret terhadap Kompetensi Pengetahuan Matematika. Jurnal Ilmiah Sekolah Dasar, 3(4). https://doi.org/https://doi.org/10.23887/jisd.v3i4.21765.

Aryantini, Agung, \& Dantes. (2018). Kontribusi Implementasi Manajemen Sekolah Berbasis Nilai-Nilai Kearifan Lokal Tri Hita Karana, Kepemimpinan Pelayan Kepala Sekolah, Budaya Sekolah dan Kepuasan Kerja Terhadap Kinerja Guru di SMP Negeri Kecamatan Sukasada Kabupaten Buleleng. $\begin{array}{llll}\text { Jurnal Administrasi } & \text { Pendidikan }\end{array}$ https://doi.org/https://doi.org/10.23887/japi.v9i2.2757.

Atmojo, S. E. (2018). Pengembangan Perangkat Pembelajaran IPA Terpadu Berpendekatan Etnosains. Jurnal Pendidikan Sains, 6(1), 5-13. https://doi.org/https://doi.org/10.26714/jps.6.1.2018.5-13

Delfia, E., \& Mayar, F. (2020). Analisis Pembelajaran Berhitung melalui Media Prisma Pintar pada Anak Usia Dini. Jurnal Obsesi: Journal of Early Childhood Education, 4(1). https://doi.org/https://doi.org/10.31004/obsesi.v4i1.350.

Dewi, M. R. S., Murda, I. N., \& Pudjawan, K. (2019). Pengaruh Model Pembelajaran Somatic Auditori Visual Intelektual (SAVI) Terhadap keterampilan Berpikir Kritis IPS Siswa Kelas V di Gugus III Kecamatan Gianyar Kabupaten Gianyar Tahun Pelajaran 2017/2018. Mimbar PGSD Undiksha, 7(1). https://doi.org/http://dx.doi.org/10.23887/jjpgsd.v7i1.17022.

Dewi, N. P. D. A., Wiyasa, I. K. N., \& Asri, I. G. A. A. S. (2017). Pengaruh Model Kooperatif Talking Stick Berbantu Question Card terhadap Kompetensi Pengetahuan IPS Siswa kelas IV. Mimbar PGSD, 5(2). https://doi.org/http://dx.doi.org/10.23887/jjpgsd.v5i2.10790.

Dewi, Semara, \& Putra. (2013). Pengaruh Model Pembelajaran Siklus Belajar “(Learning Cycle)” 5E terhadap Hasil Belajar IPA Siswa Kelas V SDN 26 Pemecutan Denpasar Barat. Mimbar PGSD Undiksha, 2(1), 1-13. https://doi.org/http://dx.doi.org/10.23887/jjpgsd.v1i1.1207.

Dwitantra, P. (2015). Pengembangan Perangkat Pembelajaran Model Discovery \& Course Review Horay (Disco) Pada Pembelajaran Lagu Daerah Nusantara Kelas 5 Sekolah Dasar Berbasis Kurikulum 2013. Journal of Primary Education, https://doi.org/https://doi.org/10.15294/jpe.v3i2.6966.

Elfa, S. (2017). Penggunaan Model Pembelajaran Interaktif Berbasis Aktivitas Untuk Meningkatkan Prestasi Belajar Siswa Kelas VI Pada Pelajaran PKN SD Negeri 09 Kabawetan. Jurnal Ilmiah Pendidikan Guru Sekolah Dasar, 10(2). https://doi.org/https://doi.org/10.33369/pgsd.10.2.66- 
72.

Hapsari, T. R., Rambita, V. M. M., \& Tindangen, M. (2018). Analisis Permasalahan Guru Terkait Perangkat Pembelajaran Berbasis Model Examples Non Examples dan Permasalahan Siswa Terkait Hasil Belajar Biologi di SMA. Jurnal Pendidikan: Teori, Penelitian, Dan Pengembangan, 3(2). https://doi.org/https://doi.org/10.17977/jptpp.v3i2.10529.

Hartini, A. (2017). Pengembangan Perangkat Pembelajaran Model Project Based Learning Untuk Meningkat Kemampuan Berpikir Kritis Siswa Sekolah Dasar. Jurnal Pendidikan Dan Pembelajaran Di Sekolah Dasar, 1(2). https://doi.org/http://dx.doi.org/10.30651/else.v1i2a.1038.

Hidayatulloh, M., Humairoh, F., Wachidah, U., Iswati, D. A., \& Suliyanah, S. (2015). Pengembangan Perangkat Pembelajaran Untuk Mereduksi miskonsepsi Siswa Pada Materi Rangkaian Listrik Dengan Saintific Approach. Jurnal Penelitian IPA Dan Aplikasinya, 5(1). https://doi.org/http://dx.doi.org/10.26740/jpfa.v5n1.p28-32.

Illahi, T. rahmah, Sukartiningsih, W., \& Subroto, W. T. (2018). Pengembangan Multimedia Interaktif pada Pembelajaran Materi Jenis-Jenis Pekerjaan Untuk Meningkatkan Kemampuan Berpikir Kritis. Jurnal Kajian Pendidikan Dan Hasil Penelitian, 4(3). https://doi.org/http://dx.doi.org/10.26740/jrpd.v4n3.p826-.

Ilmi, A. (2019). Model Pembelajaran Creative Problem Solving (Cps) Untuk Meningkatkan Performa Pemecahan Masalah Siswa. Jurnal Rekayasa, Teknologi, Dan Sains, 3, 35. https://doi.org/https://doi.org/10.33024/jrets.v3i1.1135.

Indrawan, Manuaba, \& Sujana. (2017). Pengaruh Model Pembelajaran Think Talk Write Berbasis Tri Hita Karana Terhadap Kompetensi Pengetahuan IPS Jurusan Pendidikan Guru Sekolah Dasar. Mimbar PGSD Undiksha, 5(2). https://doi.org/http://dx.doi.org/10.23887/jjpgsd.v5i2.10632.

Irawana, \& Taufina, T. (2020). Penggunaan Metode Problem Solving untuk Meningkatkan Motivasi dan Hasil Penilaian Pendidikan Kewarganegaraan Peserta Didik di Sekolah Dasar. Jurnal Basicedu, 4(2), 434-442. https://doi.org/https://doi.org/10.31004/basicedu.v4i2.367.

Istiqlal, M. (2017). Pengembangan Multimedia Interaktif dalam Pembelajaran Matematika. Jurnal Ilmiah Pendidikan Matematika, 2(2), 43-3. https://doi.org/https://doi.org/10.26877/jipmat.v2i1.1480.

Manurung, \& Panggabean. (2020). Improving Students' Thinking Ability In Physics Using Interactive Multimedia Based Problem Solving. Cakrawala Pendidikan, 39(2), 460-470. https://doi.org/https://doi.org/10.21831/cp.v39i2.28205.

Mediatati, N., \& Suryaningsih, I. (2017). Penggunaan Model Pembelajaran Course Review Horay Dengan Media Flipchart Sebagai Upaya Meningkatkan Hasil Belajar PKn. Jurnal Ilmiah Sekolah Dasar, 1(2). https://doi.org/http://dx.doi.org/10.23887/jisd.v1i2.10146.

Nugroho, R. (2018). Pengembangan Perangkat Pembelajaran Dengan Pendekatan Contextual Teaching And Learning Untuk Meningkatkan Motivasi Dan Hasil Belajar Bagi Siswa Kelas Iv Sekolah Dasar. Jurnal Bidang Pendidikan Dasar, 2(2). https://doi.org/https://doi.org/10.21067/jbpd.v2i2.2638.

Nuraziza, \& Suwarma. (2018). Menggali Keterampilan Creative Problem Solving yang dimiliki Peserta didik SMP melalui Pembelajaran IPA Berbasis STEM. Jurnal WAPFI (Wahana Pendidikan Fisika), 3(1), 55-61. https://doi.org/https://doi.org/10.17509/wapfi.v3i1.10941.

Pramestika, R. A., Suwignyo, H., \& Utaya, S. (2020). Model Pembelajaran Creative Problem Solving pada Kemampuan Berpikir Kreatif dan Hasil Belajar Tematik Siswa Sekolah Dasar. Jurnal Pendidikan Universitas Negeri Malang, 361-366. https://doi.org/http://dx.doi.org/10.17977/jptpp.v5i3.13263.

Prasetya, Nur, \& Akbar. (2018). Multimedia Interaktif pada Pembelajaran Tematik untuk Kelas IV Sekolah Dasar. Jurnal Pendidikan: Teori, Penelitian, Dan Pengembangan, 3(11), 1423-1427. https://doi.org/http://dx.doi.org/10.17977/jptpp.v3i11.11751.

Prayito. (2011). Pengembangan Perangkat Pembelajaran Matematika Humanistik Berbasis Konstruktivisme Berbantuan E-Learning Materi Segitiga Kelas VII. AKSIOMA Journal of Mathematics Education, 2(2). https://doi.org/https://doi.org/10.26877/aks.v2i2/Septembe.37.

Purnomo, H., \& Wilujeng, I. (2016). Pengembangan Bahan Ajar dan Instrumen Penilaian IPA Tema Indahnya Negeriku Penyempurnaan Buku Guru dan Siswa Kurikulum 2013. Jurnal Prima Edukasia, 4(1), 67-68. https://doi.org/https://doi.org/10.21831/jpe.v4i1.7697.

Puspitasari, \& Murda. (2018). Pengaruh Model Pembelajaran IOC Berbantuan Media Audio Visual terhadap Hasil Belajar IPS. Mimbar PGSD Undiksha, 6(2). https://doi.org/http://dx.doi.org/10.23887/jjpgsd.v6i2.19470.

Qondias, D., Winarta, \& Siswanto. (2019). Pengembangan Bahan Ajar Berbasis Pendekatan Saintifik pada Mata Kuliah Metodologi Penelitian. Jurnal Penelitian Dan Pengembangan Pendidikan, 3(2), 145148. https://doi.org/doi.org/10.23887/jppp.v3i2.17393.

Ratnawati, Handayani, \& Hadi. (2020). Pengaruh Model Pembelajaran PBL Berbantu Question Card 
terhadap Kemampuan Berpikir Kritis Matematis Siswa SMP. Edumatica: Jurnal Pendidikan Matematika, 10(1). https://doi.org/https://doi.org/10.22437/edumatica.v10i01.7683.

Retnowati, I., Yazid Fathoni, \& Chen, O. (2018). Mathematics Problem Solving Skill Acquisition: Learning By Problem Posing Or By Problem Solving. Cakrawala Pendidikan, 37(1), 1-10. https://doi.org/https://doi.org/10.21831/cp.v37i1.18787.

Rusnilawati, R. (2016). Pengembangan perangkat pembelajaran matematika bercirikan active knowledge sharing dengan pendekatan saintifik kelas VIII. Jurnal Riset Pendidikan Matematika, 3(2). https://doi.org/https://doi.org/10.21831/jrpm.v3i2.10633.

Saguni, F. (2013). Efektivitas Metode Problem Based Learning, Cooperative Learning Tipe Jigsaw, Dan Ceramah Sebagai Problem Solving Dalam Matakuliah Perencanaan Pembelajaran. Cakrawala Pendidikan, 1(2). https://doi.org/https://doi.org/10.21831/cp.v0i2.1478.

Sakaningsih, Asri, \& Negara. (2014). Model Pembelajaran Creative Problem Solving Berbasis Reinforcement Berpengaruh Terhadap Hasil Belajar PKn siswa kelas V SD N 18 Dangin Puri. Mimbar PGSD Undiksha, 2(1). https://doi.org/http://dx.doi.org/10.23887/jjpgsd.v2i1.3030.

Setyadi, I. M. A., Sudiarta, I. G. P., \& Mertasari, N. M. S. (2019). The effect of predict-observe-explain ( POE) learning model using open- ended problem ( OEP ) towards students ' mathematical problem solving skill. Jurnal Pendidikan Dan Pengajaran, 52(3), 133-144. https://doi.org/http://dx.doi.org/10.23887/jpp.v52i3.15713.

Suartama, I. K. (2016). Materi 4 Evaluasi dan Kriteria Kualitas Multimedia Pembeajaran. Singaraja: Undiksha.

Surjono, J. (2016). Pengembangan Multimedia Pembelajaran Bahasa Inggris Untuk Pembelajaran Teks Recount Di Mtsn II Yogyakarta. Jurnal Inovasi Teknologi Pendidikan, 3(1), 25-39. https: //doi.org/https://doi.org/10.21831/tp.v3i1.8287.

Suryantari, N. M. E., Suadnyana, I. N., \& Wulandari, I. G. A. . (2018). Pengaruh Model Time Token Berbasis Tri Hita Karana Terhadap Kompetensi Pengetahuan IPA Siswa Kelas IV. Pendidikan Multikultural Indonesia, 1. https://doi.org/http://dx.doi.org/10.23887/jpmu.v1i2.20773.

Tegeh, I. M. (2014). Model Penelitian Pengembangan. Graha Ilmu.

Widiartini, P. D. O., Putra, M., \& Manuaba, S. (2018). Pengaruh Model Pembelajaran Group Investigation Berbasis Tri Hita Karana Terhadap Kompetensi Pengetahuan IPA. Jurnal Ilmiah Sekolah Dasar, 3(1). https://doi.org/http://dx.doi.org/10.23887/jisd.v3i3.19476.

Widiyasanti, M., \& Ayriza, Y. (2018). Pengembangan Media Video Animasi untuk Meningkatkan Motivasi Belajar dan Karakter Tanggung Jawab Siswa Kelas V. Jurnal Pendidikan Karakter, 8(1). https://doi.org/https://doi.org/10.21831/jpk.v8i1.21489.

Widnyana, I. G., Sujana, I. W., \& Putra, I. K. A. (2017). Pengaruh Model Pembelajaran Role Playing Berbasis Tri Hita Karana Terhadap Kompetensi Pengetahuan IPS Kecamatan Denpasar Timur Tahun Pelajaran 2016 / 2017. Mimbar PGSD Undiksha, 5(2). https://doi.org/http://dx.doi.org/10.23887/jjpgsd.v5i2.11995.

Wirdaningsih, S., \& I Made Arnawa, A. A. (2017). Pengembangan Perangkat Pembelajaran Matematika dengan Pendekatan Contextual Teaching and Learning untuk Meningkatkan Kemampuan Pemecahan Masalah Peserta Didik Kelas XI. JNPM (Jurnal Nasional Pendidikan Matematika), 1(2). Retrieved from http://jurnal.ugj.ac.id/index.php/JNPM/article/view/535/446.

Yerizon, Y., Putri, Y. U., Musdi, E., \& Permana, D. (2020). Efektivitas Perangkat Pembelajaran Matematika Berbasis Pendekatan Contextual Teaching and Learning Terhadap Kemampuan Komunikasi Matematis. AKSIOMA: Jurnal Program Studi Pendidikan Matematika, 9(1), 205. https://doi.org/10.24127/ajpm.v9i1.2305.

Yuanta, F. (2019). Pengembangan Media Video Pembelajaran Ilmu Pengetahuan Sosial pada Siswa Sekolah Dasar. Jurnal Pendidikan Dasar, 1(2). https://doi.org/http://dx.doi.org/10.30742/tpd.v1i02.816. 